\title{
Sociodemographic Factors for Vitamin D Levels in Children with Acute Respiratory Infection
}

\author{
Esther Ngozi Umeadi ${ }^{1}$, Sylvia Tochukwu Echendu', Chinyelu Uchenna Ufoaroh ${ }^{2}$, \\ Ernest Ndukaife Anyabolu ${ }^{3}$, Ezinne Ifeyinwa Nwaneli ${ }^{1}$, Wilson Chukwuneke Igwe ${ }^{1}$, \\ Chijioke E. Ezeudu1', Ekene Agatha Emeka1, Joy Chinelo Ebenebe1, Ifeoma Egbuonu1 \\ ${ }^{1}$ Department of Pediatrics, Nnamdi Azikiwe University, Nnewi, Nigeria \\ ${ }^{2}$ Department of Medicine, Nnamdi Azikiwe University, Nnewi, Nigeria \\ ${ }^{3}$ Department of Medicine, Chukwuemeka Odumegwu Ojukwu University, Awka, Nigeria \\ Email: *enhealer@yahoo.com
}

How to cite this paper: Umeadi, E.N., Echendu, S.T., Ufoaroh, C.U., Anyabolu, E.N., Nwaneli, E.I., Igwe, W.C., Ezeudu, C.E., Emeka, E.A., Ebenebe, J.C. and Egbuonu, I. (2021) Sociodemographic Factors for Vitamin D Levels in Children with Acute Respiratory Infection. Open Journal of Pediatrics, 11, 759-769.

https://doi.org/10.4236/ojped.2021.114070

Received: November 10, 2021

Accepted: December 12, 2021

Published: December 15, 2021

Copyright $\odot 2021$ by author(s) and Scientific Research Publishing Inc. This work is licensed under the Creative Commons Attribution International License (CC BY 4.0).

http://creativecommons.org/licenses/by/4.0/

\begin{abstract}
Background and Objectives: Childhood acute respiratory infection is a public health problem with significant morbidity and mortality in developing countries. The present study was to assess the sociodemographic determinants of vitamin D levels in patient with acute respiratory infections (ARIs) receiving care in Nnamdi Azikiwe University Teaching Hospital (NAUTH), Nnewi, Southeast Nigeria. Methodology: This was a cross-sectional study, conducted in Nnewi, Nigeria, on 250 children with ARI. Sociodemographic data were collected and serum vitamin D levels of the subjects were assayed. The association between sociodemographic variables and vitamin $\mathrm{D}$ was evaluated using multivariate logistic regression analysis. Results: A total of 250 children with ARI aged 1 - 59 months were enrolled in this study, with slight male preponderance $(57.2 \%)$. About $60 \%$ of the population was less than 2 years. The majority (85.6\%) of the subjects had adequate vitamin D levels $(\geq 20 \mathrm{ng} / \mathrm{dL}$ ). The mean serum vitamin $\mathrm{D}$ level in the subjects was $(52.2 \pm 25.6 \mathrm{ng} / \mathrm{mL})$. Multivariate logistic regression showed that only gender was significantly related to vitamin $\mathrm{D}$ levels with males found to have a lower risk of vitamin $\mathrm{D}$ deficiency. $\{\mathrm{OR}=0.05(0.004-0.77)\}, \mathrm{p}=0.03$. Conclusion: The association between male gender and high levels of vitamin D in acute respiratory infection was significant in this study. Further studies, however, should explore a probable role for vitamin D supplementation in children with ARI.
\end{abstract}

\section{Keywords}

Vitamin D Deficiency, Under-Five Children, Acute Respiratory Infection, Gender 


\section{Introduction}

Vitamin D is a prohormone largely involved in the homeostasis of calcium and phosphorous. It aids in both the absorption and excretion of calcium and phosphorous. It aids in the maintenance of humoral and cell-mediated immunity and immune modulation by its effect on some cytokine production and release [1]. Vitamin D aids erythropoiesis and reduces the risk of anaemia and its attendant consequences [2] In recent years, vitamin D status and its potential health benefits have received much attention in research [3] [4] [5]. Vitamin $\mathrm{D}$ is important in the normal growth and development of bones and teeth and improved resistance against certain diseases [3]. It improves mood and eases occasions of anxiety and depression [4] [5]. Low levels of vitamin D increase the risk of cardiovascular, gastrointestinal and respiratory diseases both infectious and non-infectious. It also reduces the risk of cognitive impairment, autoimmune diseases, cardiovascular disease and cancers in adulthood [6] [7] [8] although there is no consistent evidence [9]. Vitamin D is important in immune system maturation and higher vitamin $\mathrm{D}$ levels are linked to the low prevalence of asthma and reduced risks of respiratory infections [10] [11]. Vitamin D is a unique micronutrient as the primary source is solar ultraviolet B radiation which converts 7 -dehydrocholesterol to vitamin $\mathrm{D}_{3}$ in the skin with oral supplementation representing an important secondary source [5]. This function makes vitamin D, re-emergence of vitamin D deficiency and the involvement of vitamin $\mathrm{D}$ in various aspects of life an important target for public health intervention [4]. To better identify children at higher risk and to define strategies to improve vitamin D status, it is important to recognize the sociodemographic determinants of vitamin $\mathrm{D}$ status.

This study aimed at assessing the influence of sociodemographic characteristics on serum vitamin D levels of these under-five children with ARI who presented to the children's clinic. Several studies have been documented in other parts of the world seeking association of vitamin D deficiency and sociodemographic characteristics. This study would evaluate the association between serum vitamin D levels and the sociodemographic features in children who had ARTI in NAUTH, Nigeria.

\section{Materiaals and Methods}

\subsection{Study Area}

The study was conducted in the children out-patient clinic and children's Emergency room of Nnamdi Azikiwe University Teaching Hospital (NAUTH) Nnewi, Anambra State, Nigeria. NAUTH is a tertiary institution in Anambra, Southeast Nigeria. The hospital maintains a paediatric clinic, which runs Monday to Friday every week from 8.0 am to $4.0 \mathrm{pm}$ and 24-hour emergency room headed by two consultant paediatricians.

Study design: This study was cross-sectional and hospital-based. 


\subsection{Study Participant/Recruitment}

The subjects were 250 under-five children who presented at the Children's Outpatient Clinics (CHOP) and Children Emergency Room (CHER) of NAUTH, Nnewi, diagnosed with acute respiratory tract infections. Participants whose parents/caregivers gave consent were recruited consecutively as they presented.

\subsection{Sampling Method}

All eligible participants who met the inclusion criteria and those whose parents/caregivers gave consent were recruited by convenient sampling as they presented to CHER and CHOP until the required sample size was attained. Each subject was assigned a study identification number which was used to label the specimen bottles. Children with chronic diseases, malnourishment and those on anticonvulsants were excluded from the study.

\subsection{Data Collection}

Data were collected using pretested questionnaires administered by the researchers and their research assistants. The research assistants were 3 house officers trained on how to administer the questionnaire to the Parent/Caregiver and the techniques of blood sample collection. They assisted in that capacity.

Diagnosis of ARI was made based on clinical presentations and examination findings [12] [13] [14] [15].

\subsection{Sample Collection/Storage}

Two millilitres of venous blood were collected from each participant for vitamin $\mathrm{D}$ assay under aseptic technique. The serum of each blood sample was separated and labelled with a study identification number.

Separated samples were stored in refrigerators at a temperature of $-20^{\circ} \mathrm{C}$ [16] and monitored with a Fisherbrand thermometer and Eurolab ST9269B multithermometer until analysis. Analysis was done using ELISA with the assistance of a laboratory scientist.

\subsection{Data Analysis}

Data collected were entered in excel and analysed using the Statistical Package for the Social Sciences (SPSS) version 21 (IBM SPSS statistics 21). The relevant means and standard deviation were calculated for normally distributed continuous variables such as age and serum vitamin D level. Categorical variables were presented as percentages for gender, place of residence, social class. Multivariate regression analysis was done to determine the correlation between sociodemographic factors and vitamin D levels in children with ARI.

A $p$ value of $<0.05$ was deemed statistically significant. Findings were presented using appropriate frequency tables and charts.

Socio-economic class was assigned to each participant using Oyedeji's classification [17]. 
Socio-economic class (SEC) is defined as:

The sum of father's occupation and education scores plus mother's occupation and education scores is divided by four. Oyedeji's classification has a total of ten points. Five points each for both occupation and educational status. It is the social standing or class of an individual or group.

Low SEC $=4-5$;

Middle SEC $=3$;

High SEC $=1-2$.

Vitamin D status in relation to serum 25-hydroxy vitamin D level was documented based on the America Academy of Paediatrics (AAP) [18] and Institute of Medicine(IOM) [19] reports as follows: Severe deficiency as $<5 \mathrm{ng} / \mathrm{mL}(0-$ $12.5 \mathrm{nmol} / \mathrm{L})$, Deficiency as $5-<15 \mathrm{ng} / \mathrm{mL}(12.5-37.5 \mathrm{nmol} / \mathrm{L})$, Insufficiency as $15-<20 \mathrm{ng} / \mathrm{mL}(37.5-50 \mathrm{nmol} / \mathrm{L})$, Sufficiency as $20-100 \mathrm{ng} / \mathrm{mL}(50-<250$ $\mathrm{nmol} / \mathrm{L})$ and Excess as $100-150 \mathrm{ng} / \mathrm{mL}(250-372.5 \mathrm{nmol} / \mathrm{L})$. These cut off points were used because of the IOM report that at $\geq 20 \mathrm{ng} / \mathrm{mL}(50 \mathrm{nmol} / \mathrm{L})$ the vitamin D needs of majority of the population is met [19].

\subsection{Ethical Consideration}

Ethical clearance for the study was obtained from the Ethics Committee of NAUTH, Nnewi. Permission to conduct the study was also obtained from the Head of Department of Paediatrics, NAUTH, Nnewi. Written informed consent was obtained from each participant's parent/caregiver before enrolling the selected subjects into the study after educating them on the overall nature and possible benefits of the study and the role the result of the study may play in improving the management of the patients. Participation in the study was voluntary. No penalty was borne by those who declined inclusion. Every information obtained from the subjects and their controls were treated confidentially as all information was coded. The researcher bore the financial costs for the laboratory tests and no incentives were provided for them.

\section{Results}

A total of 250 children with ALRI aged 1 - 59 months were enrolled in the study.

There was a slight preponderance of males among the subjects (57.2\%). The number of subjects in each age strata were (1 - 12 months) 90 (36\%), (12 - 23 months) 60 (24\%), (24 - 35 months) 40 (16\%), (36 - 47 months) 30 (12\%) and (48 - 59 months) 30 (12\%) (Table 1 and Table 2). Most of the subjects resided in urban areas (56.8\%). Flat (36.8) and tenement (poor housing) (36.4\%) were the most common accommodation types for the Subjects. The low socio-economic class was the commonest (49.2\%) while the middle and high classes were $41.6 \%$ and $9.2 \%$ respectively. Most of the subjects had sufficient vitamin D levels greater than $20 \mathrm{ng} / \mathrm{dL}$ (85.6\%). The proportion of the subjects that had low vitamin D levels was $10.8 \%$. The mean serum vitamin D levels of the subjects were $52.2 \pm 25.6 \mathrm{ng} / \mathrm{mL}$ (Table 2). More females than males had low vitamin D levels. 
Table 1. Sociodemographic Characteristics of the Subjects.

\begin{tabular}{|c|c|}
\hline Characteristic & Subjects n (\%) \\
\hline \multicolumn{2}{|l|}{ Gender } \\
\hline Male & $143(57.2)$ \\
\hline Female & $107(42.8)$ \\
\hline \multicolumn{2}{|l|}{ Age (moths) } \\
\hline$<12$ & $90(36.0)$ \\
\hline $12-23$ & $60(24.0)$ \\
\hline $24-35$ & $40(16.0)$ \\
\hline $36-47$ & $30(12.0)$ \\
\hline $48-59$ & $30(12.0)$ \\
\hline Mean \pm SD & $19.4 \pm 14.8$ \\
\hline \multicolumn{2}{|l|}{ Residence } \\
\hline Urban & $142(56.8)$ \\
\hline Rural & $108(43.2)$ \\
\hline \multicolumn{2}{|c|}{ Type of accommodation } \\
\hline Tenement & $91(36.4)$ \\
\hline Flat & $92(36.8)$ \\
\hline Bungalow & 49 (19.6) \\
\hline Semi-detached & $18(7.2)$ \\
\hline \multicolumn{2}{|l|}{ Social class } \\
\hline High & $23(9.2)$ \\
\hline Middle & $104(41.6)$ \\
\hline Low & $123(49.2)$ \\
\hline
\end{tabular}

$\mathrm{SD}=$ standard deviation; $\mathrm{n}=$ number of subjects.

Table 2. Serum vitamin D level among the subjects.

\begin{tabular}{ccc}
\hline Vitamin D category & $\mathbf{n} / \%$ & Mean \pm SD \\
\hline Severe Deficiency & $2(0.8)$ & $4.8 \pm 0.2$ \\
Deficiency & $9(3.6)$ & $11.9 \pm 1.6$ \\
Insufficiency & $16(6.4)$ & $17.9 \pm 1.6$ \\
Sufficiency & $214(85.6)$ & $54.6 \pm 20.0$ \\
Excess & $9(3.6)$ & $116.8 \pm 11$. \\
Total & $250(100)$ & $52.2 \pm 25.6$
\end{tabular}

$\mathrm{SD}=$ standard deviation; ${ }^{*}$ statistically significant; $\mathrm{n}=$ number of subjects.

Vitamin D deficiency and insufficiency were commonest among those aged 24 35 months and 48 - 59 months respectively, those residents in urban areas, residing in bungalows, or belonging to middle and low socioeconomic status 
(Table 3). Gender $\{$ O.R $=0.05(0.004-0.77), \mathrm{p}=0.03$ was found to be statistically significant. Male children were found to have a lower risk of having vitamin D deficiency/insufficiency (Table 4).

Table 3. Relationship between serum vitamin D status and socio-demographic characteristics among subjects.

\begin{tabular}{|c|c|c|c|c|c|c|}
\hline Characteristics & $\begin{array}{l}\text { Deficiency } \\
\mathrm{n}=11(\%)\end{array}$ & $\begin{array}{l}\text { Insufficiency } \\
n=16(\%)\end{array}$ & $\begin{array}{c}\text { Normal } \\
\mathrm{n}=214(\%)\end{array}$ & $\begin{array}{c}\text { Excess } \\
\mathrm{n}=9(\%)\end{array}$ & $\mathrm{X}^{2}$ & $\mathrm{p}$ value \\
\hline \multicolumn{7}{|l|}{ Gender } \\
\hline Male & $6(4.2)$ & $8(5.6)$ & $126(88.1)$ & $3(2.1)$ & 2.71 & 0.44 \\
\hline Female & $5(4.7)$ & $8(7.5)$ & $88(82.2)$ & $6(5.6)$ & & \\
\hline \multicolumn{7}{|l|}{ Age (months) } \\
\hline$<12$ & $2(2.2)$ & $4(4.4)$ & $78(86.7)$ & $6(6.7)$ & 6.34 & 0.41 \\
\hline $12-23$ & $2(3.3)$ & $5(8.4)$ & $51(85.0)$ & $2(3.3)$ & & \\
\hline $24-35$ & $5(12.5)$ & $2(5.0)$ & $33(82.5)$ & $0(0.0)$ & & \\
\hline $36-47$ & $1(3.3)$ & $1(3.3)$ & $27(90.1)$ & $1(3.3)$ & & \\
\hline $48-59$ & $1(3.3)$ & $4(13.3)$ & $25(83.4)$ & $0(0.0)$ & & \\
\hline \multicolumn{7}{|l|}{ Locality } \\
\hline Urban & $7(4.9)$ & $10(7.0)$ & $121(85.2)$ & $4(2.8)$ & 0.99 & 0.80 \\
\hline Rural & $4(3.7)$ & $6(5.6)$ & $93(86.1)$ & $5(4.6)$ & & \\
\hline \multicolumn{7}{|l|}{ Type of Residence } \\
\hline Tenement & $4(4.4)$ & $4(4.4)$ & $78(85.7)$ & $5(5.5)$ & 4.75 & 0.58 \\
\hline Flat & $5(5.4)$ & $5(5.4)$ & $79(85.9)$ & $3(3.3)$ & & \\
\hline Bungalow & $2(4.1)$ & $7(14.3)$ & $39(79.6)$ & $1(2.0)$ & & \\
\hline Semi-detached & $0(0.0)$ & $0(0.0)$ & $18(100.0)$ & $0(0.0)$ & & \\
\hline \multicolumn{7}{|l|}{ Social Class } \\
\hline High & $1(4.4)$ & $1(4.4)$ & $20(86.8)$ & $1(4.4)$ & 3.06 & 0.38 \\
\hline Middle & $5(4.8)$ & $6(5.8)$ & $87(83.7)$ & $6(5.8)$ & & \\
\hline Low & $5(4.1)$ & $9(7.3)$ & $107(87.0)$ & $2(1.6)$ & & \\
\hline
\end{tabular}

$\mathrm{n}=$ number of subjects.

Table 4. Risk factors for vitamin D deficiency/insufficiency among subjects.

\begin{tabular}{ccc}
\hline Factor & O. R $(95 \% \mathrm{CI})$ & p value \\
\hline Gender & $0.05(0.004-0.77)$ & $0.03^{*}$ \\
Age & $1.53(0.54-4.32)$ & 0.43 \\
Residence & $1.88(0.28-12.80)$ & 0.52 \\
Type of accommodation & $0.48(0.36-6.09)$ & 0.59 \\
Social Class & $0.77(0.13-4.69)$ & 0.78 \\
\hline
\end{tabular}

O.R $=$ Odd's ratio, 95\% CI = 95\% Confidence Interval, *statistically significant. 


\section{Discussion}

This present study assessed the effect of sociodemographic factors on vitamin D levels of under-five children with ARI. The demographic variables considered were gender, age, residence, type of accommodation and socioeconomic class. About $85.6 \%$ of the population had normal vitamin D levels $>20 \mathrm{ng} / \mathrm{dL}$ which is the lowest recommended level by IOM [19]. The mean vitamin D levels were $52.3 \pm 25.6 \mathrm{ng} / \mathrm{dL}$.

The levels of vitamin $\mathrm{D}$ was higher amongst the males $\{\mathrm{OR}=0.05(0.004$ $0.77)\}, p=0.03$. Similar findings were seen in epidemiological study done on vitamin D and gender which reported lower vitamin D levels in females when compared to males [20]. Also, a national health and nutrition survey conducted in the United States showed that male children and adolescents had statistically significant higher levels than females [21]. Similarly, Garg et al. in India and Nichols et al. in Jordan reported the same finding [22] [23]. An explanation of these higher levels of vitamin D may be because males have higher tendencies of indulging in outdoor activities than females. This is contrary to the finding of Basatemu [24]. where boys younger than 5 years had a higher prevalence of low vitamin D levels. However, several studies done in Nigeria reported no gender differences in Nigerian children [25] [26] [27]. Reasons for this could be due to differences in the seasons' vitamin $\mathrm{D}$ was assayed, lifestyles and laboratory variabilities.

Several studies on vitamin D status have shown an indirect relationship with age as serum values decrease with increasing age [21] [28] [29] [30]. This is because, with aging, there is a decrease in concentration of 7-dehydrocholesterol in the skin resulting in decreased production of vitamin D. Studies done in the paediatric population have shown a similar trend [30] [31] [32]. Mansbach proposed that the higher levels in the younger age group could be due to immaturity of skin pigmentation with skin colour developing as they grow older [30]. However, Omole et al. and Adegoke found no such association [26] [27].

In the under-five age group, several pieces of research have been done with diverse findings. Studies done in Iran and Lithuania demonstrated that children less than two years had higher serum levels of vitamin D when compared to children older than two years [33] [34]. This finding was suggested to be as a result of higher consumption of vitamin D supplements in the younger age group. Oginni et al. in Nigeria also noted that children less than three years had higher plasma concentrations of vitamin D compared to older children [35]. This is in contrast with the findings of Ahmed et al. also in Nigeria where younger age was associated with serum $25 \mathrm{OH}$ vitamin D less than $50 \mathrm{nmol}$ [25]. Wayse et al. also documented an increase in vitamin D status with age [36]. Nevertheless, this current study showed no significant effect of age on vitamin D levels. This was also supported by a study done by Zhou et al. who did not observe any significant difference between vitamin D status and age within this age group [37].

It is generally known that socioeconomic status influences health outcomes and it is one of the determinants of health care especially in children. As such, 
children from lower socioeconomic class are presumed to have poor health status. In this study, vitamin D levels were found to be lower in those from lower and middle socioeconomic classes. However, this finding was not statistically significant. Several other studies conducted in Nigeria showed that socioeconomic class did not have any effect on vitamin $d$ status [26] [27]. Studies carried out in India and Jordan showed that lower levels of vitamin D were commoner in children from higher socioeconomic classes [38] [39]. The researchers suggested that this could be due to lifestyle as children from poor homes spend more time outdoors compared to those from affluent homes. Amongst the under-five age group, Avagyan et al. found no relationship between serum levels of vitamin D and socioeconomic status [40] while Garg et al., however, reported low levels amongst those with higher socioeconomic status [22]. This again was suggested to be due to reduced outdoor activities. On the contrary, hypovitaminosis $\mathrm{D}$ was found among the lower socioeconomic class in a study reported by Nicolaido et al. in Greece [41]. An explanation for this could be because those children from this higher socioeconomic class are more likely fed with nutrient-rich foods fortified with vitamin D.

Overall, the male gender was shown to be at lower risk of having low vitamin $\mathrm{D}$ status and there was no significant relationship between vitamin D status and age, socioeconomic class, place of residence and accommodation.

\section{Conclusion}

The association between male gender and high levels of vitamin $\mathrm{D}$ in acute respiratory infection was significant. Further studies, however, should explore a probable role for vitamin D supplementation in children with ARI.

\section{Limitation}

ELISA used in analysing vitamin D is not as sensitive as Liquid chromatography-tandem mass spectrometry which is the gold standard of vitamin D assay.

What is already known about this topic

1) Vitamin $D$ plays a role in respiratory tract infections;

2) The exact method by which it plays this role is not certain.

What this topic contributes to knowledge

1) Males are more affected in Vitamin $D$ in acute respiratory infection;

2) There was no significant relationship between vitamin D status and age, socioeconomic class, place of residence and accommodation.

\section{Authors' Contributions}

All the authors contributed and they have all read and agreed to the final manuscript.

\section{Conflicts of Interest}

The authors declare no conflicts of interest regarding the publication of this paper. 


\section{References}

[1] Holick, M.F. (2003) Vitamin D: A Millennium Perspectives. Journal of Cellular Biochemistry, 88, 296-307. https://doi.org/10.1002/jcb.10338

[2] Kosek, M., Bern, C. and Guerrant, R.L. (2003) The Global Burden of Diarrhoeal Disease. As Estimated from Studies Published between 1992 and 2000. Bulletin of the World Health Organization, 81, 197-204.

[3] Braegger, C., Campoy, C., Colomb, V., Desci, T., Domellof, M., Fewtrell, M., et al. (2013) Vitamin D in the Healthy European Paediatric Population. Journal of Pediatric Gastroenterology and Nutrition, 56, 692-701. https://doi.org/10.1097/MPG.0b013e31828f3c05

[4] Hilger, J., Friedel, A., Herr, R., Rausch, T., Ross, F., Wahi, D.A., et al. (2014) A Systematic Review of Vitamin D Status in Populations Worldwide. British Journal of Nutrition, 111, 23-45. https://doi.org/10.1017/S0007114513001840

[5] Holick, M.F. (2007) Medical Progress: Vitamin D Deficiency. The New England Journal of Medicine, 357, 266-281. https://doi.org/10.1056/NEJMra070553

[6] Chowdhury, R., Kunutsor, S., Vitezova, A., Oliver-Williams, C., Chowdhury, S., Kiefte-de-Jong, J.C., et al. (2014) Vitamin D and Risk of Cause Specific Death: Systemic Review and Meta-Analysis of Observational Cohort and Randomized Intervention Studies. BMJ, 348, g1903. https://doi.org/10.1136/bmj.g1903

[7] Thacher, T.D. and Clarke, B.L. (2011) Vitamin D Insufficiency. Mayo Clinic Proceedings, 86, 50-60. https://doi.org/10.4065/mcp.2010.0567

[8] Bouvard, B., Annweiler, C., Salle, A., Beauchet, O., Chappard, D. and Audran, M. (2011) Extraskeletal Effects of Vitamin D: Facts, Uncertainties and Controversies. Joint Bone Spine, 78, 10-16. https://doi.org/10.1016/j.jbspin.2010.10.011

[9] Theodaratou, E., Tzoulaki, I., Zgaga, L. and Ioannidis, J.P. (2014) Vitamin D and Multiple Health Outcomes: Umbrella Review of Systematic Reviews and MetaAnalysis of Observational Studies and Randomized Trials. BMJ, 348, g2035. https://doi.org/10.1136/bmj.g2035

[10] Bozzetto, S., Carraro, S., Giordano, G., Boner, A. and Baraldi, E. (2012) Asthma, Allergy and Respiratory Infections: The Vitamin D Hypothesis. Allergy, 67, 10-17. https://doi.org/10.1111/j.1398-9995.2011.02711.x

[11] Nurmatou, U., Devereux, G. and Sheikh, A. (2011) Nutrients and Foods for the Primary Prevention of Asthma and Allergy: Systematic Review and Meta-Analysis. Journal of Allergy and Clinical Immunology, 127, 724-733. https://doi.org/10.1016/j.jaci.2010.11.001

[12] Johnson, A.W.B.R. (2007) Acute Respiratory Infections. In: Azubuike, J.C. and Nkanginieme, K.E., Eds., Paediatrics and Child Health in Tropical Region, 2nd Edition, African Educational Services, Owerri, 396-425.

[13] Olowu, A., Elusiyan, J., Esangbedo, D., Ekure, E., Esezobor, C., Falade, A., et al. (2015) Management of Community Acquired Pneumonia (CAP) in Children: Clinical Practice Guidelines by the Paediatrics Association of Nigeria (PAN). Nigerian Journal of Paediatrics, 42, 283-292. https://doi.org/10.4314/njp.v42i4.1 http://www.ajol.info/index.php/njp/article/view/122319

[14] Liu, L.L., Gallaher, M.M., Davis, R.L., Rutter, C.M., Lewis, T.C. and Marcuse, E.K. (2004) Use of a Respiratory Clinical Score among Different Providers. Pediatric Pulmonology, 37, 243-248. https://doi.org/10.1002/ppul.10425

[15] Nascimento-Carvalho, C.M. (2004) Evaluation of the Degree of Tachypnea for Hospitalizing Children with Pneumonia. Indian Pediatrics, 41, 175-179. 
[16] Nair, H., Nokes, D.J., Gessner, B.D., Dherani, M., Madhi, S.A., Singleton, R.J., et al. (2010) Global Burden of Acute Lower Respiratory Infections Due to Respiratory Syncytial Virus in Young Children: A Systematic Review and Meta-Analysis. The Lancet, 375, 1545-1555. https://doi.org/10.1016/S0140-6736(10)60206-1

[17] Oyedeji, G.A. (1985) Socio Economic and Cultural Background of Hospitalized Children in Ilesha. Nigerian Journal of Paediatrics, 12, 111-117.

[18] Chisti, M.J., Tebruegge, M., La Vincente, S., Graham, S.M. and Duke, T. (2009) Pneumonia in Severely Malnourished Children in Developing Countries-Mortality Risk, Aetiology and Validity of WHO Clinical Signs: A Systematic Review. Tropical Medicine \& International Health, 14, 1173-1189.

https://doi.org/10.1111/j.1365-3156.2009.02364.x

[19] Shimeles, D. and Lulseged, S. (1994) Clinical Profile and Pattern of Infection in Ethiopian Children with Severe Protein-Energy Malnutrition. East African Medical Journal, 71, 264-267.

[20] Verdoia, M., Schaffer, A., Barbieri, L., Di Giovine, G., Marino, P., Suryapranata, H., et al. (2015) Impact of Gender Difference on Vitamin D Status and Its Relationship with the Extent of Coronary Artery Disease. Nutrition, Metabolism \& Cardiovascular Diseases, 25, 464-470. https://doi.org/10.1016/j.numecd.2015.01.009

[21] Looker, A.C., Johnson, C.L., Lacher, D., Pfeiffer, C.M., Schleicher, R.L. and Sempos, C.T. (2011) Vitamin D Status: United States, 2001-2006. NCHS Data Brief, 127, 1-8.

[22] Garg, D., Sharma, V. and Karnawat, B. (2016) Association of Serum Vitamin D with Acute Lower Respiratory Infection in Indian Children under 5 Years: A Case Control Study. International Journal of Contemporary Pediatrics, 3, 1164-1169. https://doi.org/10.18203/2349-3291.ijcp20163141

[23] Nichols, E.K., Khatib, I.M.D., Aburto, N.J., Serdula, M.K., Scanlon, K.S., Wirth, J.P., et al. (2015) Vitamin D Status and Associated Factors of Deficiency among Jordanian Children of Preschool Age. European Journal of Clinical Nutrition, 69, 90-95. https://doi.org/10.1038/ejen.2014.142

[24] Basatemur, E., Horsfall, L., Marston, L., Rait, G. and Sutcliffe, A. (2017) Trends in the Diagnosis of Vitamin D Deficiency. Pediatrics, 139, e20162748. https://doi.org/10.1542/peds.2016-2748

[25] Ahmed, P., Babaniyi, I.B., Yusuf, K.K., Dodd, C., Langdon, G., Steinhoff, M., et al. (2015) Vitamin D Status and Hospitalisation for Childhood Acute Lower Respiratory Tract Infections in Nigeria. Paediatrics and International Child Health, 35, 151-156. https://doi.org/10.1179/2046905514Y.0000000148

[26] Omole, K.O., Kuti, B.P., Oyelami, O.A., Adegbola, A.J. and Omole, J.O. (2018) Serum Vitamin D Profile of Nigerian Children with Asthma: Association with Asthma Severity and Control. Pediatric Pulmonology, 53, 544-551.

[27] Adegoke, S.A. (2017) Prevalence and Factors Influencing Sub-Optimal Serum Levels of 25-Hydroxyvitamin D among Children with Sickle Cell Anaemia in Southwest Nigeria. Annals of Health Research, 3, 118-125.

[28] Li, W., Cheng, X., Guo, L., Li, H., Sun, C., Cui, X., et al. (2018) Association between Serum 25-Hydroxyvitamin D Concentration and Pulmonary Infection in Children. Medicine, 97, e9060. https://doi.org/10.1097/MD.0000000000009060 http://insights.ovid.com/crossref?an=00005792-201801050-00005

[29] Gallagher, J.C. (2013) Vitamin D and Aging. Endocrinology and Metabolism Clinics of North America, 42, 319-332. https://doi.org/10.1016/j.ecl.2013.02.004

[30] Ginde, A.A., Mansbach, J.M. and Camargo, C.A. (2009) Association between Serum 25-Hydroxyvitamin D Level and Upper Respiratory Tract Infection in the Third 
National Health and Nutrition Examination Survey. Archives of Internal Medicine, 169, 384-390. https://doi.org/10.1001/archinternmed.2008.560

[31] Andersson, B., Swolin-Eide, D., Magnusson, P. and Albertsson-Wikland, K. (2016) Vitamin D Status in Children over Three Decades-Do Children Get Enough Vitamin D? Bone Reports, 5, 150-152. https://doi.org/10.1016/j.bonr.2016.03.002

[32] Orluwene, C.G. and Opurum, H. (2012) 25-Hydroxycholecalciferol Levels in a Representative Sample of Children and Young Adolescents from the IkwerreSpeaking Local Government Areas of Rivers State, Nigeria. IOSR Journal of Dental and Medical Sciences, 1, 47-52. https://doi.org/10.9790/0853-0134752

[33] Torkaman, M., Abolghasemi, H., Amirsalari, S., Beiraghdar, F., Afsharpaiman, S., Kavehmanesh, Z., et al. (2016) Comparison of the Vitamin D Status of Children Younger and Older than 2 Years in Tehran: Are Supplements Really Necessary? International Journal of Endocrinology and Metabolism, 14, e34676. https://doi.org/10.5812/ijem.34676

[34] Butkutè, E., Gailiūtė, I., Drapeko, N., Grikinienè, J. and Butkutè, E. (2017) Analysis of Vitamin D Levels in Blood Serum in Children. Vitamins \& Minerals, 6, Article ID: 1000158. https://doi.org/10.4172/2376-1318.1000158

[35] Oginni, L.M., Worsfold, M., Oyelami, O.A., Sharp, C.A., Powell, D.E. and Davie, M.W.J. (1996) Etiology of Rickets in Nigerian Children. The Journal of Pediatrics, 128, 692-694. https://doi.org/10.1016/S0022-3476(96)80137-5

[36] Wayse, V., Yousafzai, A., Mogale, K. and Filteau, S. (2003) Association of Subclinical Vitamin D Deficiency with Severe Acute Lower Respiratory Infection in Indian Children under 5 Years. European Journal of Clinical Nutrition, 58, 563-567. https://doi.org/10.1038/sj.ejcn.1601845

[37] Zhao, X., Xiao, J.P., Liao, X.P., Cai, L.Y., Xu, F., Chen, D.Z., et al. (2015) Vitamin D Status among Young Children Aged 1-3 Years: A Cross-Sectional Study in Wuxi, China. PLoS ONE, 10, e0141595. https://doi.org/10.1371/journal.pone.0141595

[38] Vasudevan, J. (2014) Prevalence and Factors Associated with Vitamin D Deficiency in Indian Children: A Hospital Based Cross Sectional Study. Pediatric Oncall Journal, 11, 71-76.

https://www.pediatriconcall.com/pediatric-journal/view/fulltext-articles/851/J/0/0/0/0

[39] Gharaibeh, M.A. and Stoecker, B.J. (2009) Assessment of Serum 25(OH) D Concentration in Women of Childbearing Age and Their Preschool Children in Northern Jordan during Summer. European Journal of Clinical Nutrition, 63, 1320-1326. https://doi.org/10.1038/ejcn.2009.99

[40] Avagyan, D., Neupane, S.P., Gundersen, T.E. and Madar, A.A. (2016) Vitamin D Status in Pre-School Children in Rural Nepal. Public Health Nutrition, 19, 470-476. http://www.journals.cambridge.org/abstract_S136898001500083X https://doi.org/10.1017/S136898001500083X

[41] Nicolaidou, P., Kakourou, T., Papadopoulou, A., Kavadias, G., Dimitriou, E., Georgouli, H., et al. (2006) Low Vitamin D Status in Preschool Children in Greece. $\mathrm{Nu}$ trition Research, 26, 620-625. https://doi.org/10.1016/j.nutres.2006.09.018 